\title{
Assessment of the Smart Construction Plan for Oman Vision 2040
}

\author{
Al Mukhtar A. S. Al Farsi ${ }^{1}$ and Omar R. Khaleel ${ }^{1 \#}$ \\ ${ }^{1}$ Middle East College, Muscat, Sultanate of Oman \\ \#Advisor
}

$\underline{\text { ABSTRACT }}$

Smart construction faster and cost less (short in time with high profit), easer (less risks), perfect controlled (providing lean construction management) and should be friendly to the environment. This research focus on the evaluating future of smart construction to approach Oman vision 2040. The smart construction is to improve the building construction sector by apply lean construction management system and analysis the key factors effecting the building construction cost performance in Oman. By this the building construction will improve and can be in the path of Oman vision 2040. The main objective is evaluating future of smart construction to approach Oman 2040 vision by applying the lean construction management system for building construction industry, analysis the key factors of cost performance effecting the building construction in Oman, finding the suitable construction strategy for building construction in Oman and recommendation to government and privet sector to reduce the capital cost of the project. Methodology of this research is to approach and investigate to identify the future of smart construction to approach Oman 2040 vision. Several topics will explain such as the data collection methods, primary and secondary, the sample selection, pilot study method of analysis and limitations. Pilot study for questioner and the interviews online because of COVID 19. The factors witch effecting cost performance in building construction in Oman is part of the general results. For instance, incorrect planning and scheduling by contractor. At last, the research project explain the evaluating future of smart construction to approach Oman vision 2040. Smart construction is the building design, construction and process witch by collaborative partnerships makes a lot of technology in way of working to improve the productivity, reducing time-cost and use sustainably to improve user benefits. The research used a combination of primary data such as quantitative questionnaire survey and qualitative interviews. In addition to that secondary data used such as journals and case studies. Each type of data having a method for analysis.

\section{Introduction}

In Gulf Cooperation Council GCC countries the economy mostly depending on the oil and gas. In Oman the government started since 1980 to find other sources for the economy because it depending on oil. The government start to find out this sources such as tourism, fishing, and other sources. In 2000 the construction play a major role in the economy. Building construction have been about $15 \%$ of the Omani economy. The construction industry growth is expected about 7.1 to 7.3 per year since 2018 to 2019. (Omani construction will grow faster next year, 2020)

The process of building construction is complex and traditional fragmenting in Oman. (Oyewobi, Jimoh, Ganiyu and Shittu, 2016) Nowadays the construction sector mast be improved to keep up with the times. In 2024 in Oman the building construction industry will expected to reach 3.9 OMR billions. For that the building construction mast be smart to be faster. Smart construction faster and cost less (short in time with high profit), easer (less risks), perfect 
controlled (providing lean construction management) and should be friendly to the environment. We protect the nature and the earth when we apply sustainability even in building construction.

This research focus on the evaluating future of smart construction to approach Oman vision 2040. The smart construction is to improve the building construction sector by apply lean construction management system and analysis the key factors effecting the building construction cost performance in Oman. By this the building construction will improve and can be in the path of Oman vision 2040.

Building construction having more challenges to improve it and its profit nowadays in Oman we apply lean construction management system. The business methodology of lean is by promoting the flow of value to customers throw continue improvement and people respect. (Lean Methodology | Planview, 2020)

The system aims to five basic principles such as identify value map the value, create flow, pull and last thing continuous improvement.

By applying lean construction management system and the principles of it in building construction the work will be on time with no delays and by perfect cost for the customer. The building construction growth in Oman will keep up with times by applying the lean construction management system.

Building construction mostly depending on management. The aim of management in building construction is to control the three main factors which are time, quality \& cost. This three factors is very critical and the basic for successful building construction projects. The building construction cost performance is a major issue especially in cost of building construction projects. For the cost performance in building construction there are several key factors effecting on it. Part of this key factors is the construction strategy that can use to improve the building construction cost performance.

Approaching Oman 2040 is not easy way. There are several sectors on it such as the building construction sector which is important to us in this research. There will be plans, strategies that apple to be on the right path and on time to reach this vision. For that the building construction industry mast be smart intelligent and sustainable for now and future.

The research used a literature review and a quantitative method to find out the key factors effecting the cost performance in building construction by structure questioner survey distributed to several expert engineers works in both privet and government sector. In addition to that how to apply the lean construction management system why we should applying it in construction will explained in details in the literature review. On the other hand, the qualitative method which is used for interviews, specially made to get the recommendation to improve the government \& privet sector for the building construction industry. The main objective is evaluating future of smart construction to approach Oman 2040 vision by

- Applying the lean construction management system for building construction industry.

- Finding \& analysis the key factors of cost performance effecting the building construction in Oman.

- Finding the suitable construction strategy for building construction in Oman.

- The recommendation to government and privet sector to reduce the capital cost of the project.

\section{Methods}

\subsection{Data collection Method:}


A systematic process to gather observation or measurement is knowing as data collection. The data collection method of this research experimental research which is primarily a quantitative method and interview is a qualitative method. In addition to that secondary data collection from journals, books, publication and case studies.

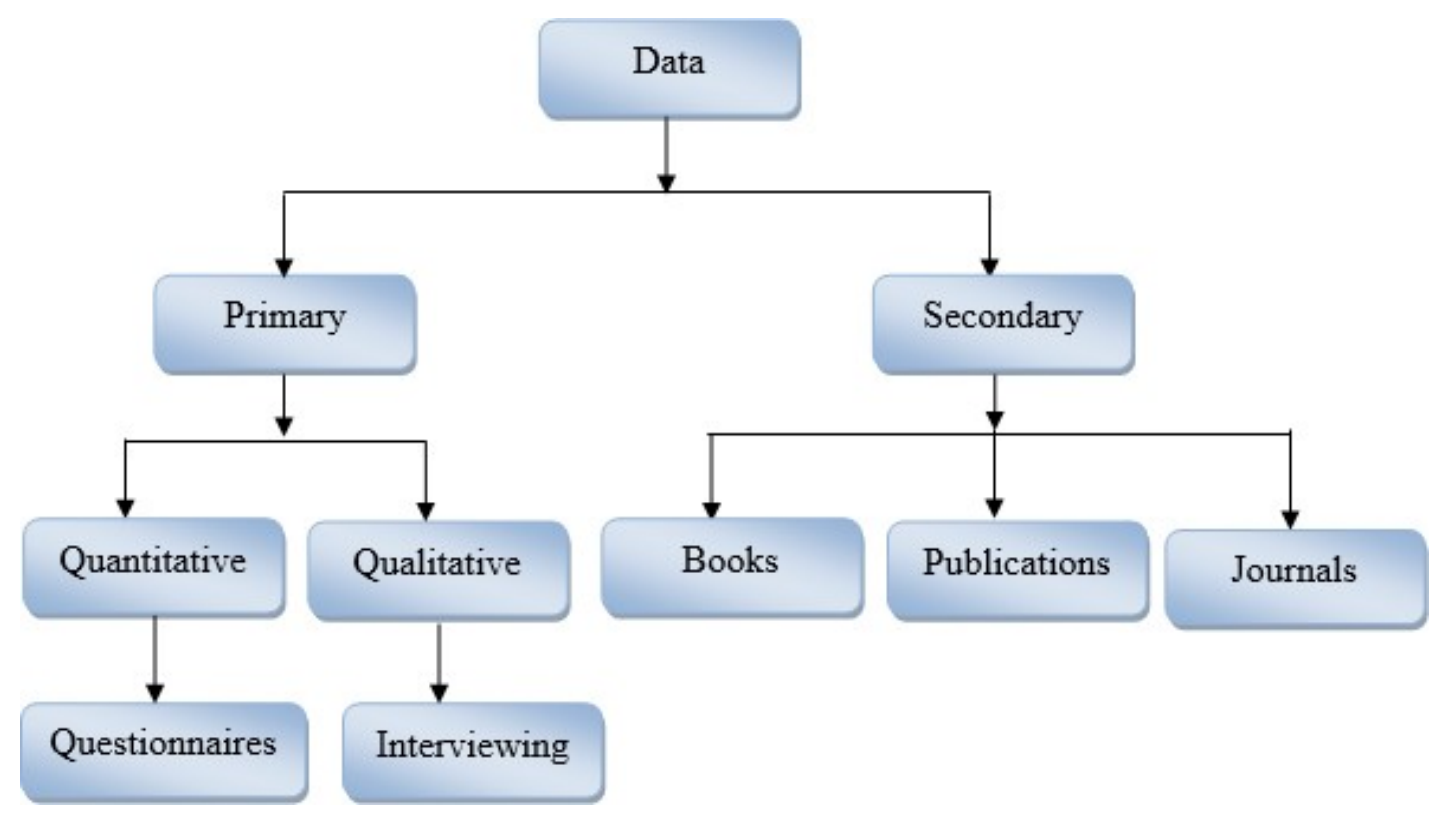

Figure 1. Data Collection Layout

\subsection{Primary Data}

The primary data is a quantitative method such as structure questioner survey and a qualitative method such as interviews. The structure questioner survey questions divided in to three parts. The first part general questions that are comment in any questioner such as gender, nationality, age, education type, organization type, and experience with the type of construction strategy prefer in building construction. The second part is ranking the factors affecting construction cost performance in building construction in Oman. The factors are from the literature review that found from the journals and case studies. For example, incorrect planning and scheduling by contractors. Also, fluctuation in prices of materials.

The third part was about lean construction management. The structure questioner survey wear distributed only for engineers. I was targeting people working in government sector and privet sector. The reason to have clear idea good result. On the other hand, for the qualitative method such as interviews I chose an expert people in the field that have big experience.

\subsection{Secondary Data}

The secondary data are from journals, publication, books and case studies such as from Muscat Municipality case. The data covers about the meaning of smart construction in the research and why approaching Oman 2040 vision. Also, the lean construction management system with the principles 
of it. In addition to that the key factors effecting the cost performance in building construction. The last thing was about the suitable construction strategy for building construction in Oman. There are several case studies wear discussed and explained for each point in the literature review.

Lean construction:

Case study of building permits in Muscat municipality.

\subsection{Factors affecting the cost performance in building construction:}

1. Case study of factors affecting construction performance.

2. Case study made in Nigeria to identify factors influencing the construction performance project.

3. Case study from journal of project Management. The issue about sustainable construction industry in Oman.

4. Case study is about identification of delay factors in construction in Oman.

\section{Construction strategy for building construction:}

The types of construction strategy are traditional method, design build method and construction management method. In addition to that the suitable construction strategy method for building construction in Oman.

\subsection{Sample selection}

The sample size is depending on the people targeting for the questioner. The population size is about 170. The z-confidence level is $95 \%$. The questioner targeting engineers working in government sector $\&$ privet sector. From the government Muscat municipality department of building permits. They have about 40 engineers. Also, some local consultancy that will give about 50 engineers \& some local construction companies $\&$ will give about 30 engineers. In addition to that 50 people how invest in building construction such as Muscat mall. The total population size about 170, the confident level $95 \%$ \& the e-margin of error is $2 \%$. For that the sample size mast be 159 and 151 responds only.

Sample size $=\frac{\frac{z^{2} \times p(1-p)}{e^{2}}}{1+\left(\frac{z^{2} \times p(1-p)}{e^{2} N}\right)}$

Equation 2: Sample Size

(Sample Size Calculator | SmartSurvey, 2020)

For the interviews I planned to do for ten expert people in the field that have big experience.

\subsection{Pilot Study}


For the questioner questions \& sample size of population some expert people in the field that have big experience made the check. Questioner was sent to three sinner engineers. One of them the general director of building primate department in Muscat Municipality. The second one project manager in ATKINS having 20 years of experience in Oman. The third one working in ASREEN Construction Company. They check the questioner questions \& gave me some notes. The questioner sent first for 15 engineers as a draft. After some modification the final one sent to the people chosen from government sector and private sector.

\subsection{Method of analysis}

Questioner analysis by software called SPSS version 25 by three methods for analysis such as Cronbach's alpha method, frequency method and crosstab. The interviews analysis manually by constant comparative method. The interviews wear online by google duo app. After that, collect data \& start coding (see the similar words). After that see the important code make it in categories. Last thing, summarize the interviews.

\section{Results and Discussion}

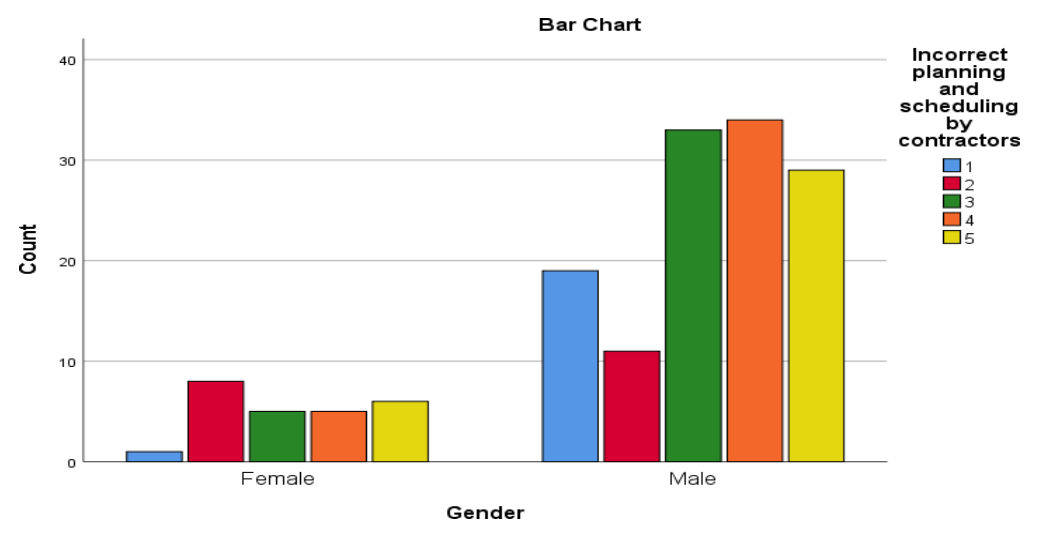

Figure 2. Gander*Incorrect planning \& scheduling by contractor

From the graph we can see that most of the participators are males and we have few females.

The in correct planning and scheduling by contractor most people agree \& strongly agree with this factor that effect the cost in building construction. This factor is a part that effect the project live cycle. The incorrect planning will lead the project to delay \& defiantly the cost overrun will be. The delay is one of the main challenges of building construction. (Sepasgozar et al., 2019) As mention in one the articles that I studied in my research project. 


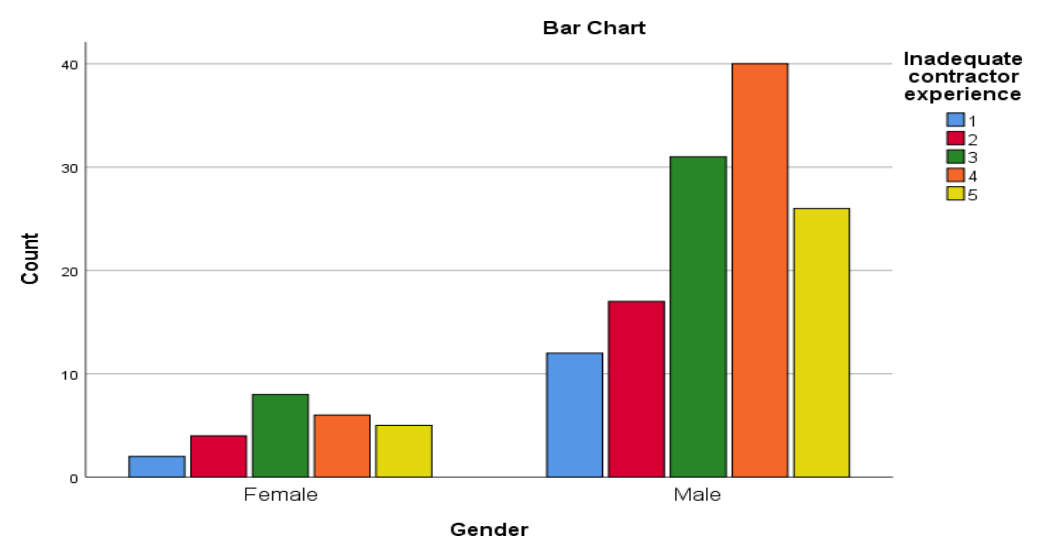

Figure 3. Gender*inadequate contract experience

The factor inadequate contract experience shows mostly participators chose agree \&strongly agree. In Oman as I mention in the literature review that the traditional strategy method is the most comment one for about $95 \%$ of design villas. The clients mostly the one how chose $\&$ bring the contractor. They make the contract between them. After that they client inform the consultancy. That wrong because the client does not have good experience in contract form.

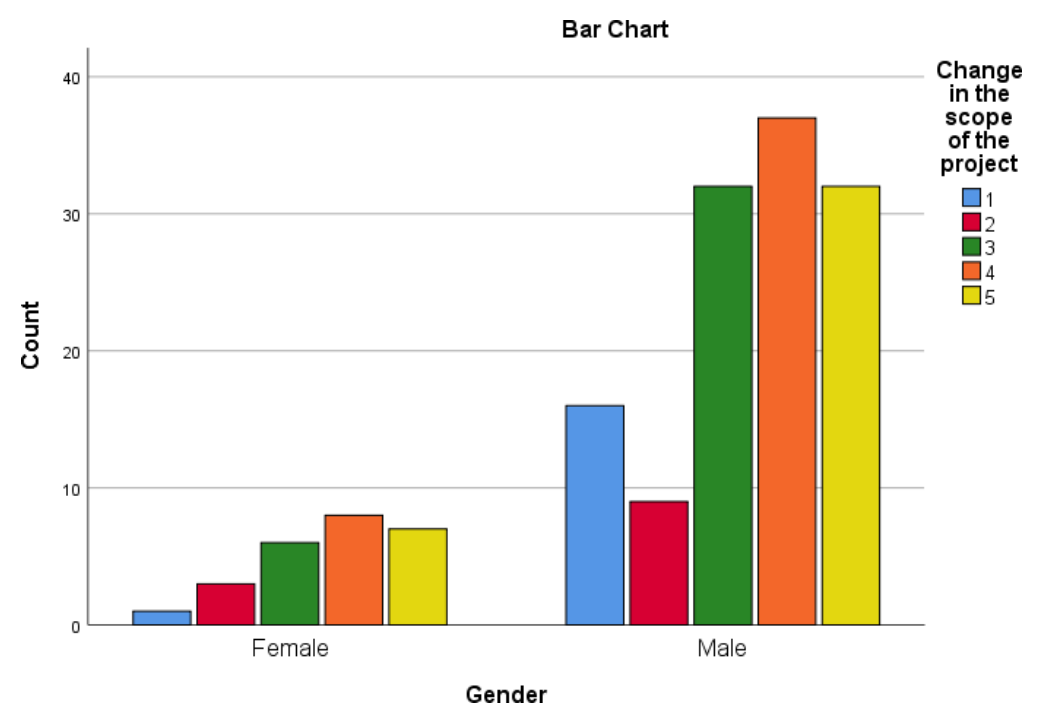

Figure 4. Gender*change in the scope of the project

The graph shows neutral, agree $\&$ strongly agree for both male $\&$ females. The change of scope of project is one of the Omanis habits will design the villa. Most people like to change their design will the construction start. Because they see different ideas from other people houses \& them in the beginning they search for sheep consultancy to design. That's why the scope of the project change. 


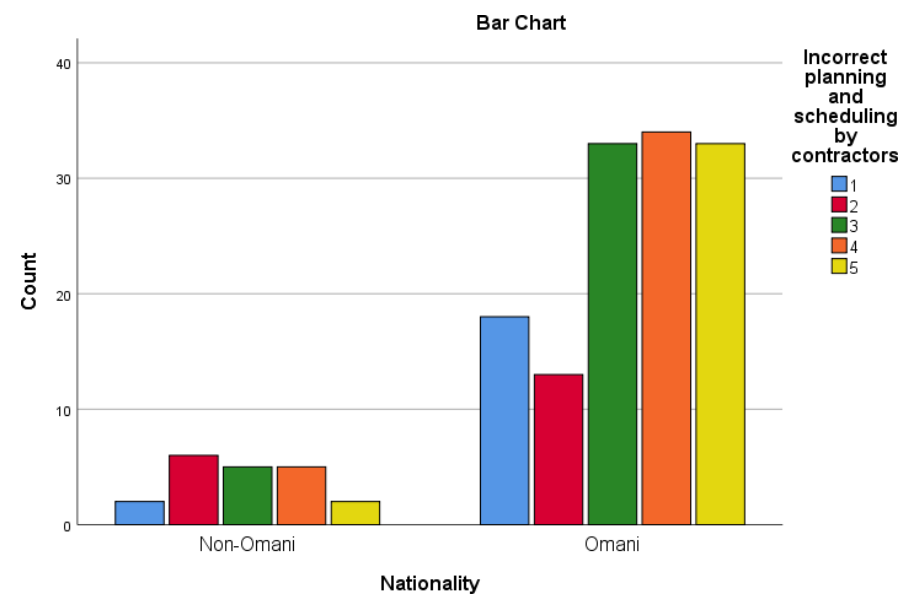

Figure 5. Nationality * incorrect planning and scheduling by contractor

Figure 5 shows a big difference that most of the participators are Omanis \& few are Non-Omanis. The Omanis mostly neutral, agree \& strongly agree that incorrect planning \& scheduling by contractor is one of the key factors that affect the cost performance in building construction. Even in the literature review I found this is one of key factors that affect the cost in building construction \& by it there will be delay in the project. In addition to that the cost will overrun. On the other hand, the Non-Omani engineers participator act that this is that effecting. This job of management \& doing the planning \& scheduling mostly don by Non-Omanis that's why it seems to them not that effect to cost performance $\&$ that's wrong thing from the research study we know that planning \& scheduling is a main part project live cycle. If any part of the project live cycle effect the hull project will effect.

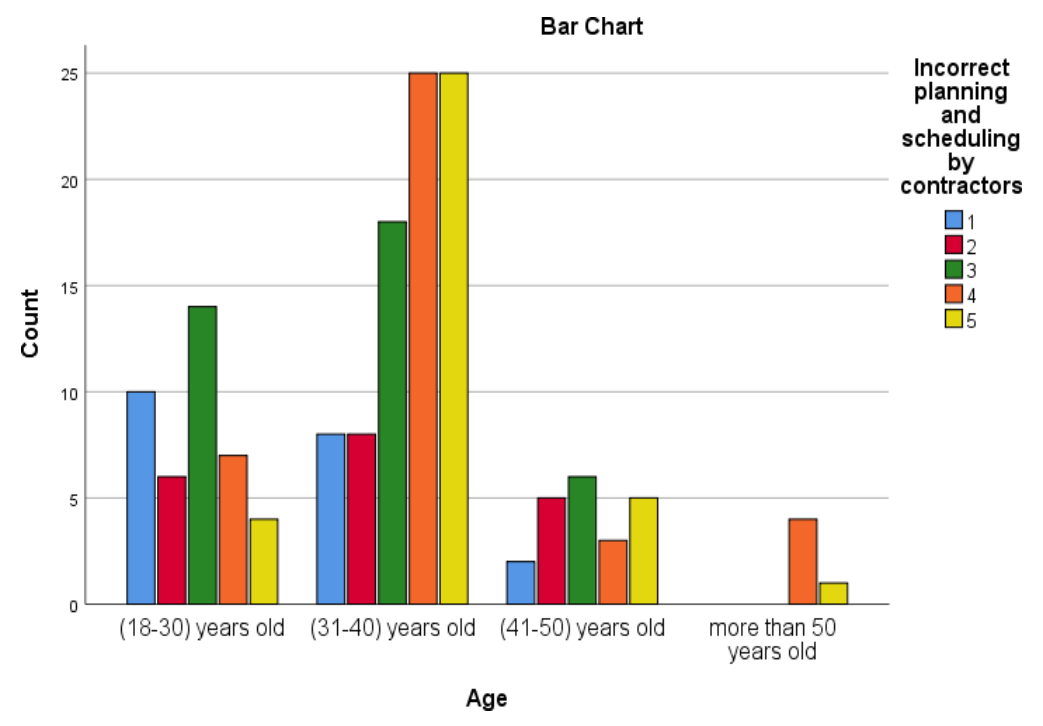

Figure 6. Age * incorrect planning and scheduling by contractor

The figure 6 shows high increase that the age between 31-40 years mostly agree $\&$ strongly agree for incorrect planning $\&$ scheduling by contractor. In addition to that the graph shows participates how respond the questioners are mostly from 31 to 41 years old. 


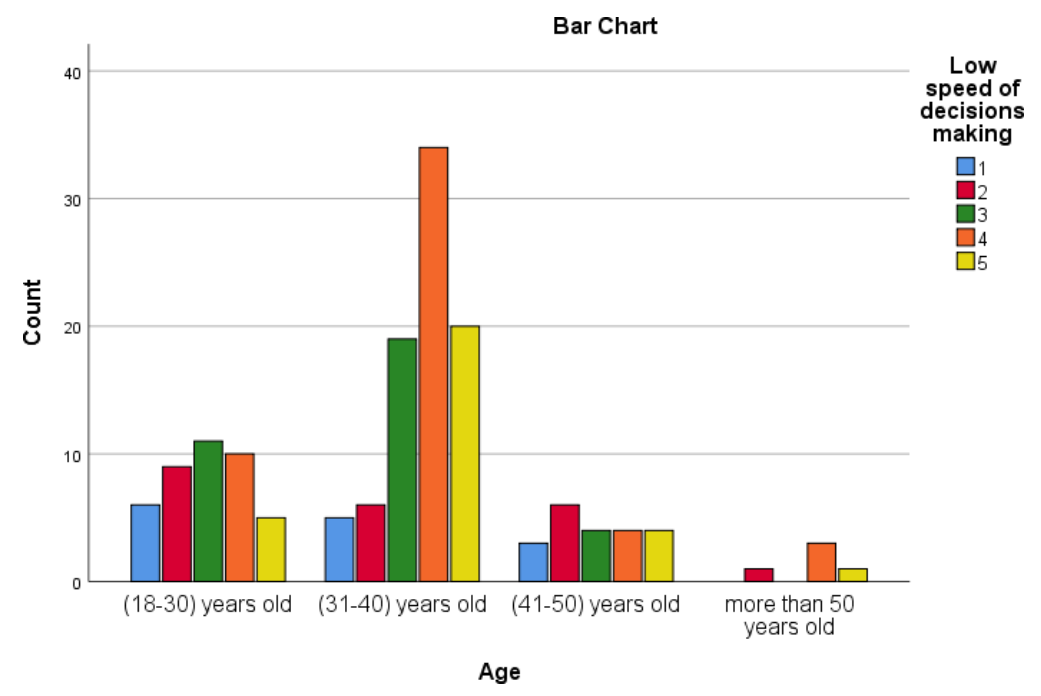

Figure 7. Age * low speed of decisions making

Figure 7 shows the age between 31-41 years agree \& strongly agree in low speed of decision making. In the site construction a lots of thangs can happen \& to reduce the risk of the project decision making mast be fast \& the plan goes as scheduled.

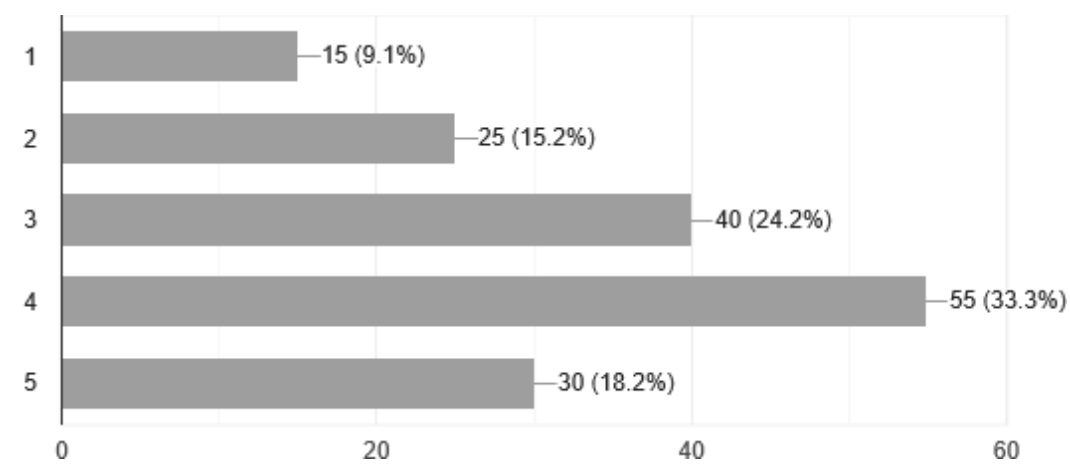

Figure 8. low speed decision making

Figure 8 shows that one of the most participates agree with this factor as one of key effecting cost performance in building construction. 


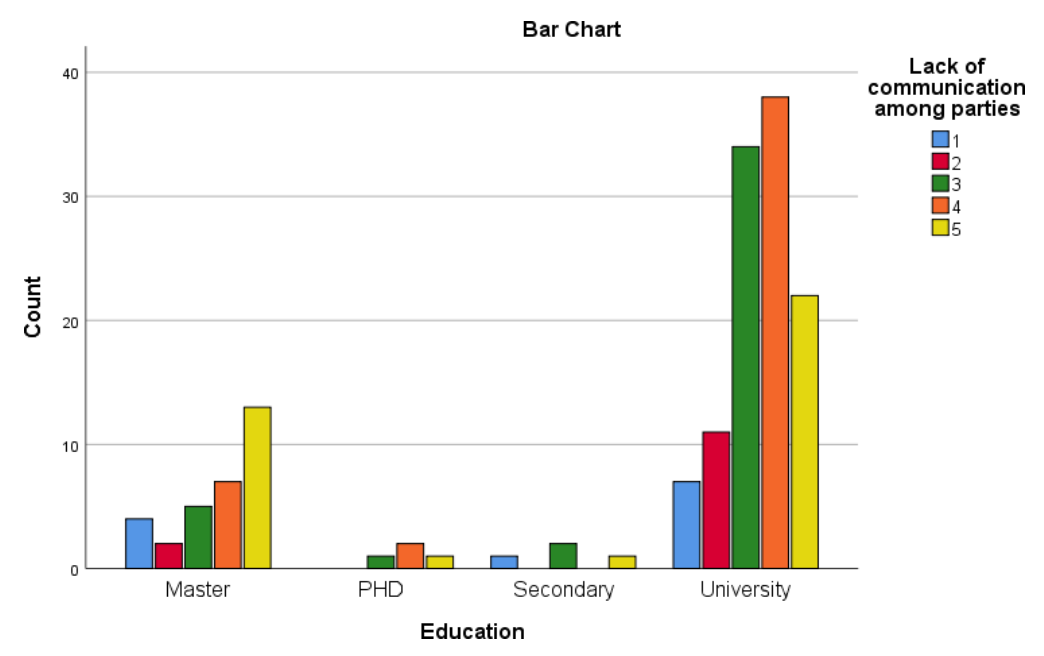

Figure 8. Education * lack of communication among parties

Figure 8 shows sharp increase in education part university type. Most of them chose agree to lack of communication among parties. As we can see from the key factors that affect the cost performance in building construction in Oman. The one mansion in the questioner that there is a link between them such as lack of communication among parties will cause low speed of decision making \& the site management will be poor. In addition to that the scope of work will change. There will be project delay \& project over cost witch is not good at all for the client.

Figure 9. lack communication among parties

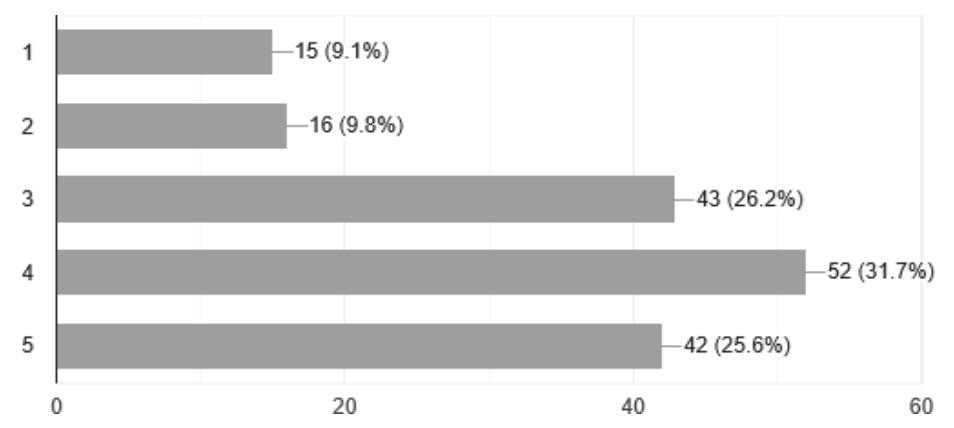

Figure 9 shows $31.7 \%$ agree for the lack communication among parties. 


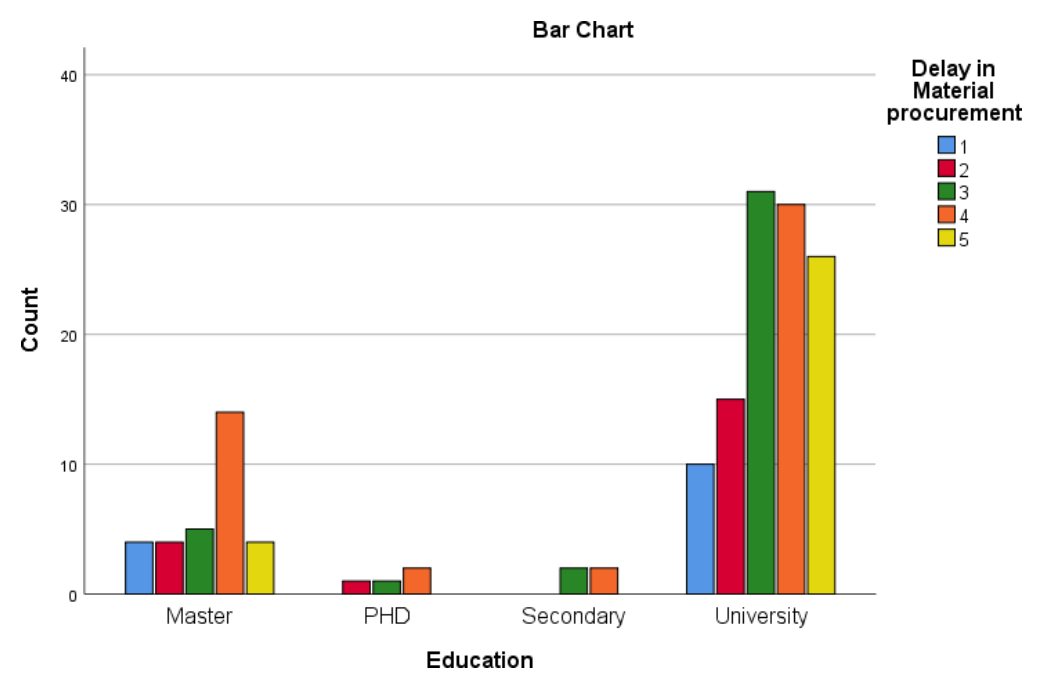

Figure 10. Education * delay in material procurement

Figure 10 shows sharp increase in university type of education. Most of them chose neutral, agree \& strongly agree for delay in, materials procurement.

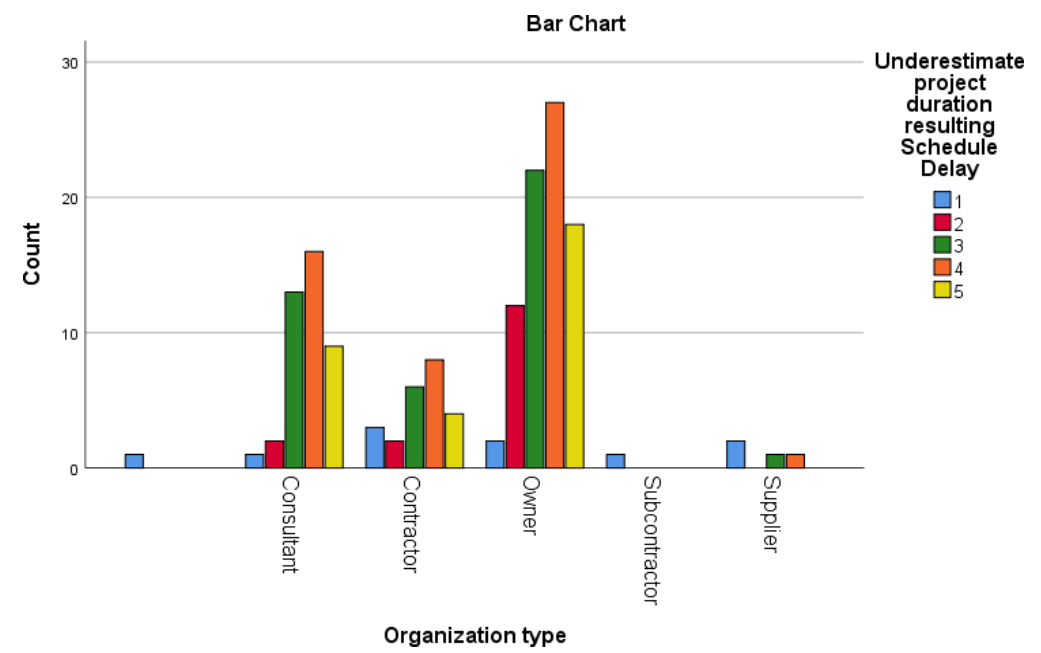

Figure 11. organization type * underestimate project duration resulting schedule delay

Figure 11 shows in most organization types neutral, agree \& strongly agree in consultancy, contractor $\&$ the heights is the owner. Underestimate project duration resulting schedule delay is one of the main key factor effecting the cost performance in building construction in Oman in as showing in the questioner. 


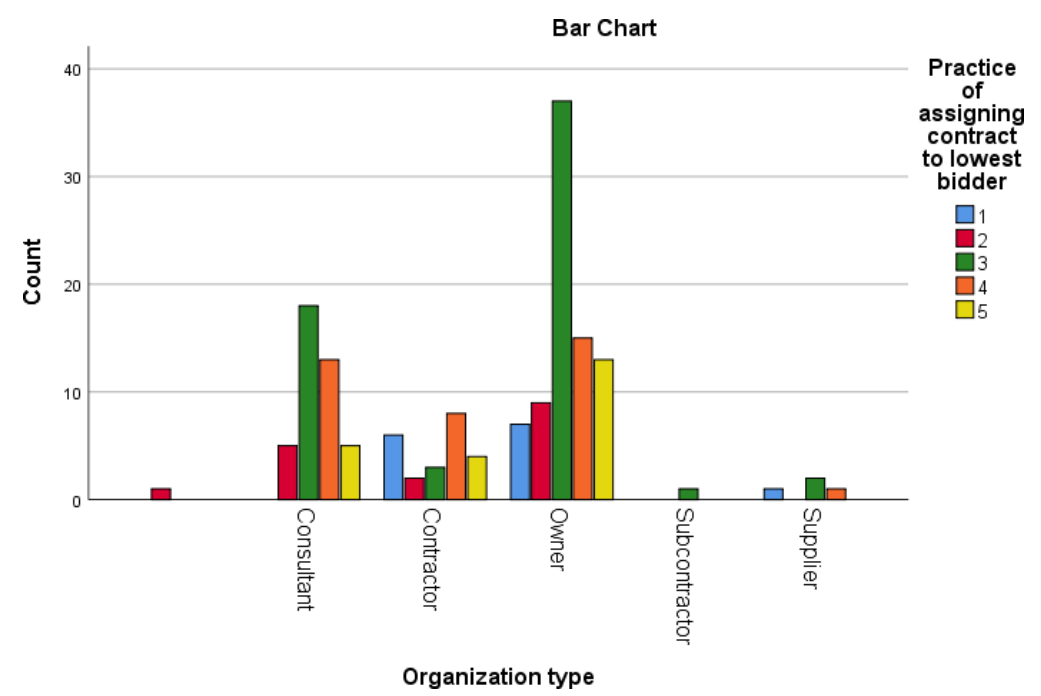

Figure 12. Organization type * practice of assigning contract to lowest bidder

Figure 11percent sharp increase for organization type owner \& chose neutral. The prices of assigning contract to lowest bidder this is one of the facts that people in Oman like to choose. In Oman the less price butter than good quality. On the other hand, the quality is butter chose. With low price can get bad contractor \& designer.

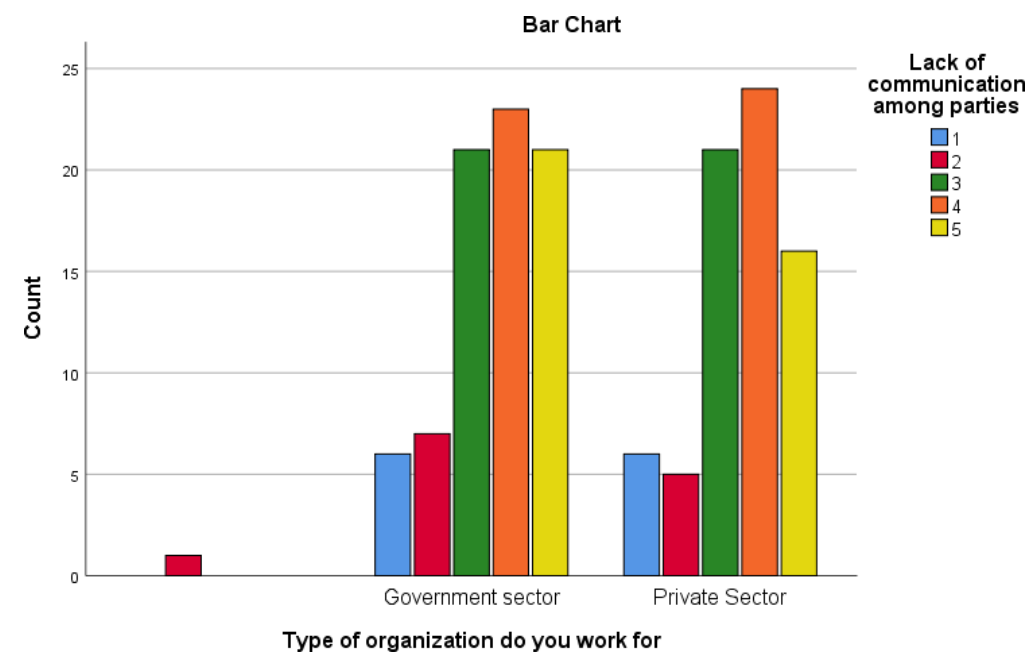

Figure 13. type of organization* lack of communication among parties

Figure 13 shows the organization type privet sector \& government sector. Both organization neutral, agree \& strongly agree chose. The lack of communication among parties is one reason to have delay \& over cost the project. 


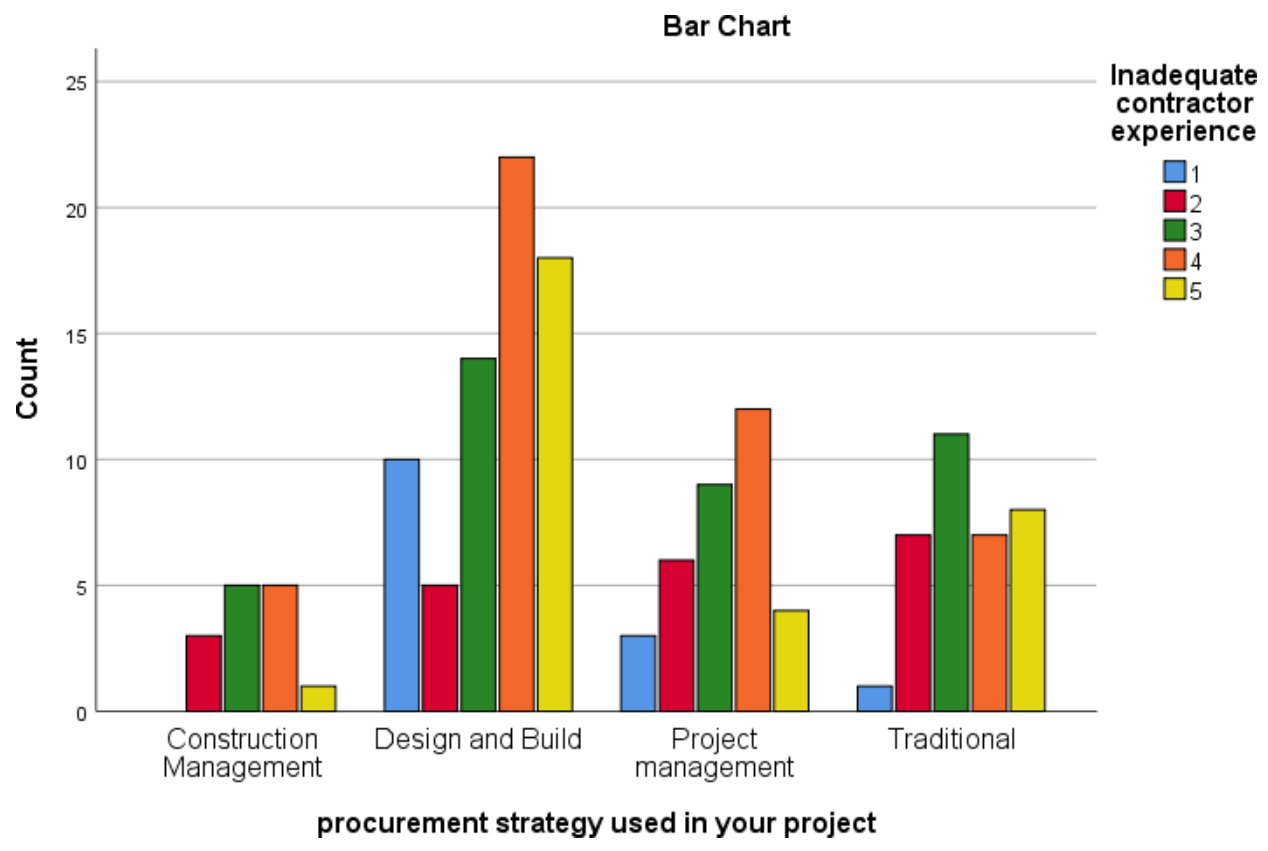

Figure 14. procurement strategy used* inadequate contract experience

Figure 14 shows that the procurement strategy used in your project mostly design $\&$ build method strategy. The design $\&$ build shows sharp increase to agree for inadequate contractor experience.

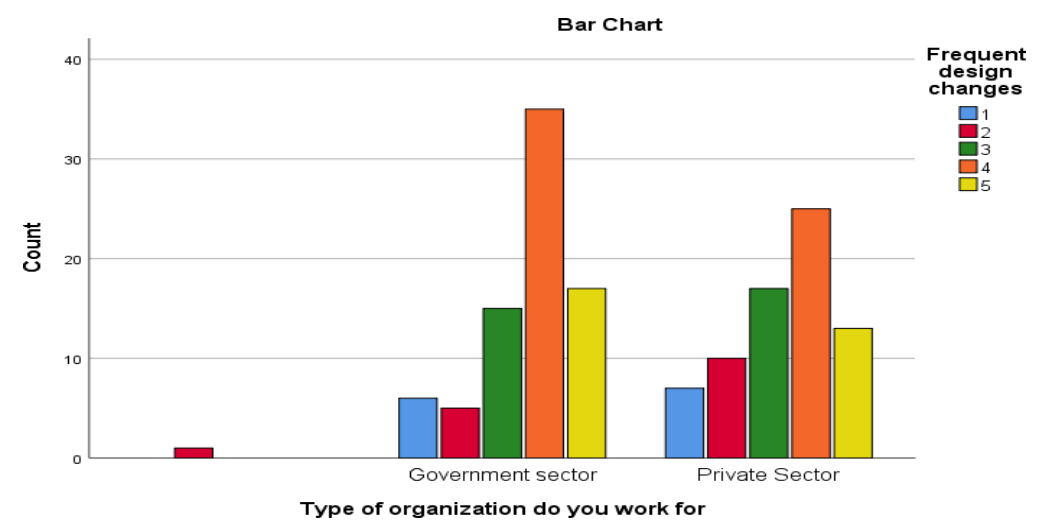

Figure 15. type of organization * frequent design change

Figure 15 shows that both organization types the government \& private sector having sharp increase for agree to frequent design changes. Design change will manly change the project live cycle $\&$ the duration with the cost.

Ranking for lean construction on site: 


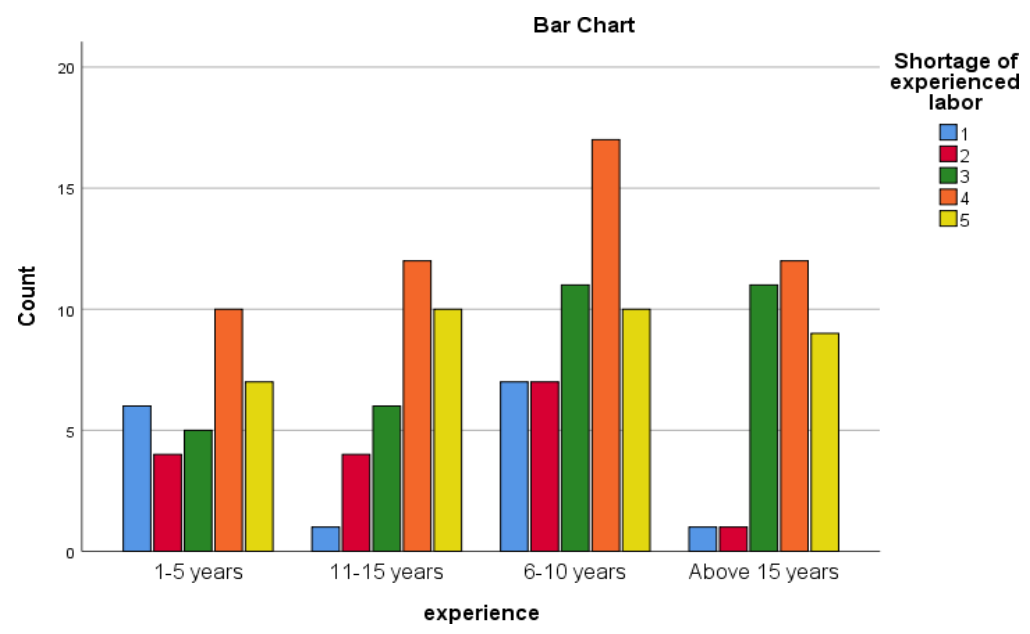

Figure 15. experience * shortage of experienced labor

Figure 15 shows experience \& the heights is 6 to 10 years. On the other hand, all experience having sharp increase for agree chose. The shortage of experienced labour is important in lean construction on site.

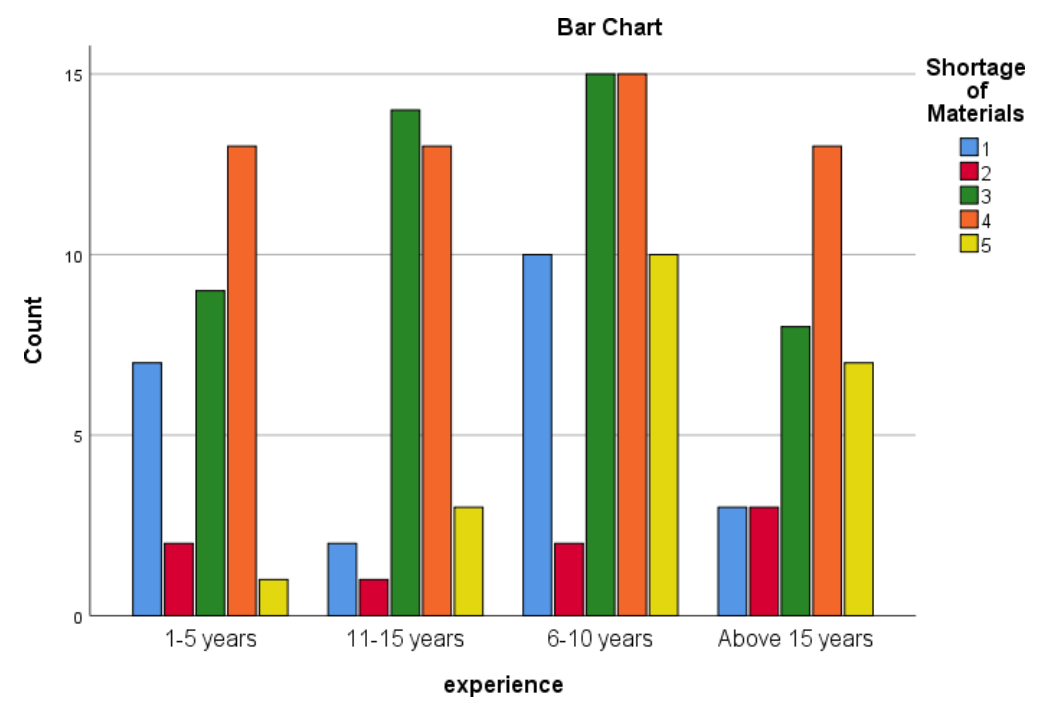

Figure 16. experience * shortage of materials

Figure 16 shows sharp increase for all experience for 1 to above 15 years. All of them agree that shortage of materials is one of the main factors for lean constriction on site \& chose agree. 


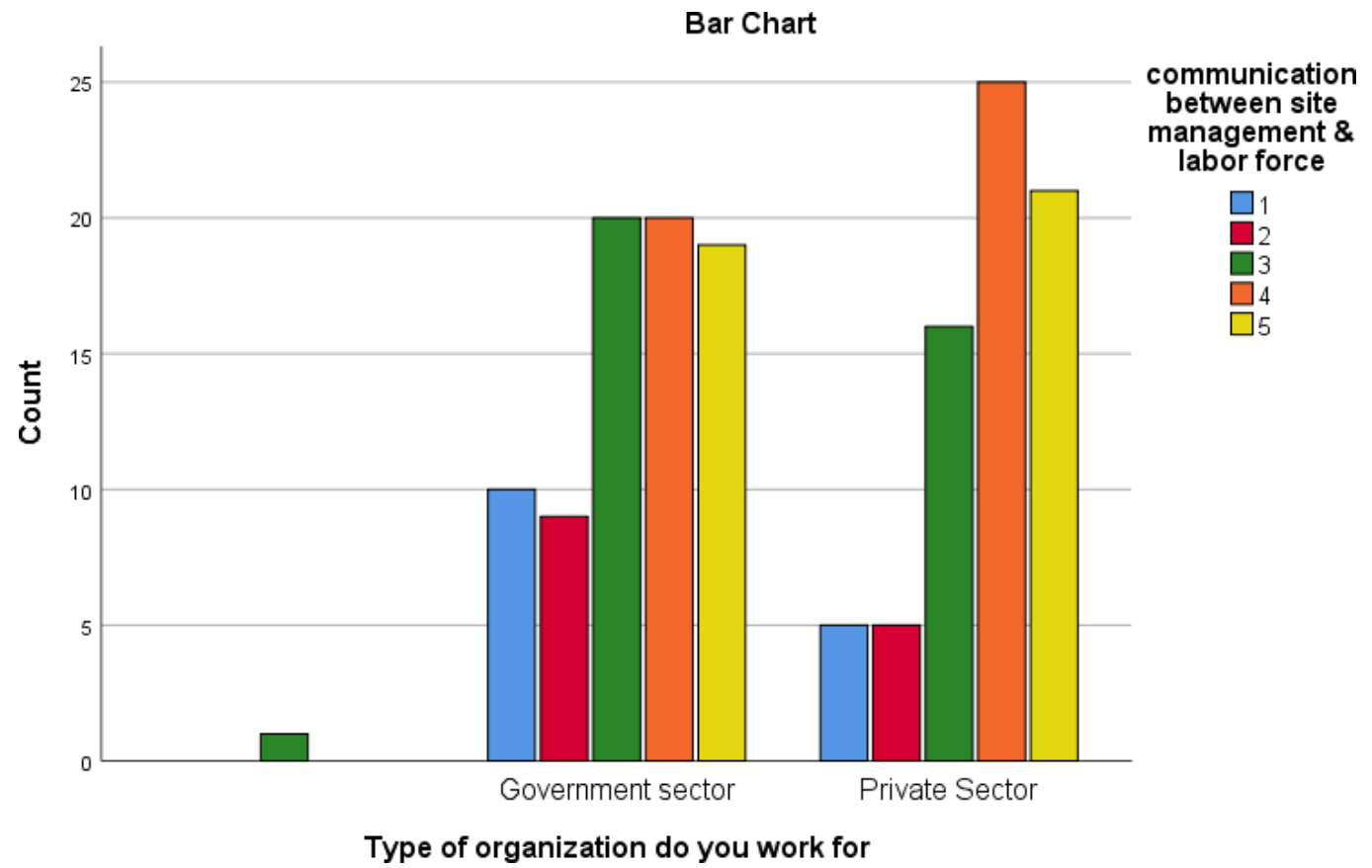

Figure 17. type of organization working in * communication between site management \& labor force

Figure 17 shows that most of privet sector agree \& strongly agree to communication between site $\&$ management $\&$ labour force. Lean construction management system mostly about control \& management.

\section{Interview analysis by Constant comparative method}

The interviews made online by google duo apps. About five interviews done. For the interview questions (see Appendices B).

The first in interview was with the Muscat Municipality general director. Having about 18 years of experience. Also, BSC in Architecture Engineering. The second one with senior project manager working in ATKINS. With 12 years' experience. The third one with Director in PDO working. About 10 years of experience. The one that providing Lean construction Management system. The fourth one a contractor having 25 years' experience in Oman. The fifth one from Emar Consultancy having 18 years' experience in building construction in Oman. In interview analysis will percent the summery of each interviews question witch done by group.

\section{Conclusion}

\section{Smart construction:}

1. Providing lean constriction management system.

2. Finding key factors effecting cost performance in building construction in Oman.

3. Fining the suitable construction strategy method for building construction project in Oman. 


\section{Oman vision 2040:}

The research helps and be part of Oman vision 2040. This will help the government when the concept will be clear in the society.

Smart construction is new path to lead to smart cities. Building construction is a part of Oman 2040 vision. The building construction economy is about $15 \%$ of all economy in Oman.

Lean Construction:

Lean construction management system is a new path with its principles for improving the building construction growth. Lean works by applying the five principles:

A- Define Value: what the customer willing to pay is the value. B- Value stream: this to identify all tasks referencing the aims. C- Create flow: checking the flow to run smoothly.

D- Pulling: the reason to limit inventory and work in process. E- Pursue: this make lean thinking and continue processing.

The Lean Construction Management in site as showing in the questioner from the first to the last one with the ranking:

1. Shortage of materials. (33.3\% agree)

2. Shortage of experienced labour. (32.7\% agree)

3. Communication between site management and labour force. (29.3\% agree)

4. Skill of labour. (27.3\% agree)

The lean construction as shows in the interviews:

In general is to reduce waste of:

- Time.

- Materials.

- Efforts.

The factors affecting cost performance in building construction in Oman: The factors affecting cost performance in building construction in Oman as showing in the questioner from the first to the last one with the ranking:

1- Frequent design change. ( $40.6 \%$ agree)

2- Practice of assigning contract to lowest bidder. (37.2\% neutral)

3- Unforeseen ground conditions. (36.4\% neutral)

4 Fluctuation in prices of materials. (35.2\% neutral)

5- Contractor's poor site management and supervision. (33.9\% agree)

6- Low speed of decisions making. (33.3\% agree)

7- $\quad$ Shortage of site workers. (32.5\% agree)

Underestimate project duration resulting Schedule Delay. (32.1\% agree)

Incompetent Project team (designers and contractors). (32.1\% neutral)

Lack of communication among parties. (31.7\% agree)

Inadequate contractor experience. ( $30.3 \%$ agree) 12 - Changing scope of the project ( $29.9 \%$ agree)

Cash flow and financial difficulty faced by contractor (29.7\% agree) 14 - Delay in Material procurement. $(29.7 \%$ agree)

Incorrect planning and scheduling don by contractors ( $26.1 \%$ neutral $)$

Key factors effecting cost performance in building construction in Oman as showing in interview:

- Major stakeholders influences:

- Clients' leadership and attitude.

- Consultants' teamwork and knowledge. 
- Contractors' experience and employees skills.

- Market conditions:

- Prices fluctuations.

- Completions level.

- Repeated instability.

- Supply and demand vitiations.

Building and construction regulations.

- Construction contract act.

- Health and safety act.

- Building agreements.

- Building instructions.

- External economic environment:

- Economic growth.

- Investment inclination.

- Natural force.

Measures of building project cost in construction:

- Capital construction cost.

- Related capital cost.

- Site acquisition and clients' other cost.

- Suitable strategy method to improve the cost performance in building construction in Oman as showing in interview:

- There is no one strategy method in building construction to fit types and sizes of the projects.

Traditional method: For villas \& residential buildings that total area not more than 10000 meters square the.

Construction management: the government projects.

Design and build: for complex design such as several villas more than 30 .

Results of the findings

In the questioners most of the participators age from 31 to 41 years and the experience from 6 to 10 years only. On other hand, for the interviews the people having not less than 15 years working in the field. This gives my different answer.

The suitable strategy method to improve the cost performance in Oman: In questioners: design and build.

In literature review and interviews: traditional method for small projects and project management for government projects.

The key factors effecting cost performance in building construction in Oman:

In questioners: short listed

In interviews: categorised each factor with several included on.

\section{Acknowledgments}

Special thanks goes to the faculty members of Department of Civil Engineering. Special thanks to the head of department, module leader, my supervisor for their guidance and support to complete this research project. I would also like to extend my gratitude to my class mates. 


\section{References}

1- 2020. [online] Available at: <https://www.researchgate.net/publication/324721530_PERSPECTIVES _ON_CONSTRUCTION_COST_OVERRUN_IN_OMAN> [Accessed 11 August 2020].

2- 2040.om. 2020. Oman Vision 2040. [online] Available at: $<$ https://www.2040.om/en/oman-vision-2040/about-the-vision/> [Accessed 21 July 2020].

3- Ahmed, S. and Sobuz, M., 2019. Challenges of implementing lean construction in the construction industry in Bangladesh. Smart and Sustainable Built Environment, 9(2), pp.174-207.

4 Amri, T. and Marey-Pérez, M., 2020. Towards a sustainable construction industry: Delays and cost overrun causes in construction projects of Oman. Journal of Project Management, pp.87-102.

5- Bajjou, M., Chafi, A. and En-Nadi, A., 2017. The Potential Effectiveness of Lean Construction Tools in Promoting Safety on Construction Sites. International Journal of Engineering Research in Africa, 33, pp.179-193.

6- Construction Week Online Middle East. 2020. Omani Construction Will Grow Faster Next Year. [online] Available at:

$<$ https://www.constructionweekonline.com/article-49769-omani- construction-will-grow-faster-next-year> [Accessed 25 August 2020].

7- Constructionleadershipcouncil.co.uk. 2020. [online] Available at: $<$ https://www.constructionleadershipcouncil.co.uk/wp- content/uploads/2018/10/181010-CLC-Smart-ConstructionGuide.pdf $>$ [Accessed 20 July 2020].

8- Edirisinghe, R., 2019. Digital skin of the construction site. Engineering, Construction and Architectural Management, 26(2), pp.184-223.

9- Ekanayake, E. and Sandanayake, Y., 2017. LiVE approach: Lean integrated Value Engineering for construction industry. Built Environment Project and Asset Management, 7(5), pp.518-533.

10- Ghansah, F., Owusu-Manu, D. and Ayarkwa, J., 2020. Project management processes in the adoption of smart building technologies: a systematic review of constraints. Smart and Sustainable Built Environment, ahead-ofprint(ahead-of-print).

11- Gupta, S., Ahmadi, M. and Kumar, L., 2020. IDENTIFICATION OF THE BARRIERS OF LEAN CONSTRUCTION IMPLEMENTATION IN CONSTRUCTION PROJECTS- A REVIEW. International Journal of Innovative Research in Computer Science \& Technology, 8(3).

12- Imran Latif, Q., Al Saadi, A. and Abdul Rahman, I., 2019. Identification of Delay Factor in Oman Construction Industry. International Journal of Sustainable Construction Engineering Technology, 10(1).

13- International Journal of Recent Trends in Engineering and Research, 2017. Critical Factors Influencing Quality Performance in Construction Projects. 3(4), pp.65-72.

14 Jiang, W., Ding, L. and Zhou, C., 2020. Cyber physical system for safety management in smart construction site. Engineering, Construction and Architectural Management, ahead-of-print(ahead-of-print).

15- Management, C., 2020. Factors Affecting Construction Cost Estimation. [online] The Constructor. Available at: $<$ https://theconstructor.org/construction/cost-estimation-factors/9316/> [Accessed 11 August 2020].

16- Medium. 2020. Ways To Make Your Construction Smart \& Sustainable. [online] Available at: $<$ https://medium.com/@prakritigroupindia/ways- to-make-your-construction-smart-sustainable-539e63bba21> [Accessed 20 July 2020].

17- My Website. 2020. Reducing Time Spent In Processes In Industrial Sector To Nearly 75 Percent In Five 
Governmental Entities. [online] Available at: $<$ https://omannews.gov.om/NewsDescription/ArtMID/392/ArticleID/926 9/Reducing-Time-Spent-in-Processes-inIndustrial-Sector-to-nearly-75- Percent-in-Five-Governmental-Entities> [Accessed 7 August 2020].

18- Olawumi, T. and Chan, D., 2020. Key drivers for smart and sustainable practices in the built environment. Engineering, Construction and Architectural Management, 27(6), pp.1257-1281.

19- Oman Observer. 2020. Oman'S First Smart Office Building Taj Inaugurated. [online] Available at: $<$ https://www.omanobserver.om/omans-first-smart-office-building-taj-inaugurated/> [Accessed 20 July 2020].

20- Oyegoke, A. and Al Kiyumi, N., 2017. The causes, impacts and mitigations of delay in megaprojects in the Sultanate of Oman. Journal of Financial Management of Property and Construction, 22(3), pp.286-302.

21- Oyegoke, A. and Al Kiyumi, N., 2017. The causes, impacts and mitigations of delay in megaprojects in the Sultanate of Oman. Financial Management of Property and Construction, 22(3), pp.286-302.

22- Oyewobi, L., Jimoh, R., Ganiyu, B. and Shittu, A., 2016. Analysis of causes and impact of variation order on educational building projects. Journal of Facilities Management, 14(2), pp.139-164.

23- Planview. 2020. Lean Methodology | Planview. [online] Available at: $<$ https://www.planview.com/resources/articles/lean-methodology/> [Accessed 25 August 2020].

24 Riddell, T., 2020. What Is Lean Construction \& Why You Should Care - Esub Construction Software. [online] eSUB Construction Software. Available at: <https://esub.com/lean-construction-care/> [Accessed 21 July 2020].

25- Røberg, Ø., 2020. The Impact Of Scope Management On Project Success. [online] Safran.com. Available at: $<$ https://www.safran.com/blog/why- scope-management-is-essential-for-project-success $>$ [Accessed 5 September 2020].

26- Saleh, M. and Alalouch, C., 2015. Towards Sustainable Construction in Oman: Challenges \& Opportunities. Procedia Engineering, 118, pp.177- 184.

27- Sarhan, J., Xia, B., Fawzia, S., Karim, A., Olanipekun, A. and Coffey, V., 2019. Framework for the implementation of lean construction strategies using the interpretive structural modelling (ISM) technique. Engineering, Construction and Architectural Management, 27(1), pp.1-23.

28- Sepasgozar, S., Karimi, R., Shirowzhan, S., Mojtahedi, M., Ebrahimzadeh, S. and McCarthy, D., 2019. Delay Causes and Emerging Digital Tools: A Novel Model of Delay Analysis, Including Integrated Project Delivery and PMBOK. Buildings, 9(9), p.191.

29- Shahsavand, P., Marefat, A. and Parchamijalal, M., 2018. Causes of delays in construction industry and comparative delay analysis techniques with SCL protocol. Engineering, Construction and Architectural Management, 25(4), pp.497-533.

30- Shurrab, J. and Hussain, M., 2018. An empirical study of the impact of lean on the performance of the construction industry in UAE. Journal of Engineering, Design and Technology, 16(5), pp.694-710.

31- Silverio-Fernandez, M., Renukappa, S. and Suresh, S., 2019. Evaluating critical success factors for implementing smart devices in the construction industry. Engineering, Construction and Architectural Management, 26(8), pp.1625-1640.

32- Smartsurvey.co.uk. 2020. Sample Size Calculator | Smartsurvey. [online] Available at: $<$ https://www.smartsurvey.co.uk/sample-size-calculator $>$ [Accessed 27 August 2020].

33- Soewin, E. and Chinda, T., 2018. Factors affecting construction performance: exploratory factor analysis. IOP Conference Series: Earth and Environmental Science, 140, p.012102.

34 Stonemark Construction Management. 2020. What Is Procurement In Construction Management? - Stonemark. [online] Available at: $<$ https://stonemarkcm.com/blog/procurement-in-construction- management/> [Accessed 2 September 2020]. 
35- The Lean Way. 2020. The Five Principles Of Lean. [online] Available at: $<$ https://theleanway.net/The-Five-Principles-of-Lean> [Accessed 6 August 2020].

36- Zhou, S., Zhang, X., Liu, J., Zhang, K. and Zhao, Y., 2020. Exploring development of smart city research through perspectives of governance and information systems: a scientometric analysis using CiteSpace.

Journal of Science and Technology Policy Management, ahead-of- print(ahead-of-print).

37- Zidane, Y. and Andersen, B., 2018. The top 10 universal delay factors in construction projects. International Journal of Managing Projects in Business, 11(3), pp.650-6. 